\title{
Leaf Morphological Traits of then Shrub Species at the Tamaulipan Thorn Scrub
}

\author{
Perla Cecilia Rodriguez Balboa ${ }^{1}$, Humberto Gonzalez Rodriguez ${ }^{1 *}$, Israel Cantu Silva ${ }^{1}$, Artemio Carrillo Parra ${ }^{1}$ and \\ Roque G. Ramirez Lozano²
}

${ }^{1}$ Facultad de Ciencias Forestales, Carr. Nac. Num. 85, km 145 Linares, Nuevo Leon (67 700), Mexico

${ }^{2}$ Facultad de Ciencias Biologicas, San Nicolas de los Garza, Nuevo Leon (67 700), Mexico

\section{Article History}

Manuscript No. AR1494b

Received in $21^{\text {st }}$ November, 2015

Received in revised form $14^{\text {th }}$ March, 2016

Accepted in final form $4^{\text {th }}$ April, 2016

\section{Correspondence to}

*E-mail: humberto.gonzalezrd@uanl.edu.mx

\section{Keywords}

leaf morphological traits, Tamaulipan thorn scrub shrub correlation analysis

\begin{abstract}
The aim of this work was to conduct a research study of the leaf morphological traits of ten woody species that grow and develop in the Tamaulipan Thorn scrub Shrub land. Study species were Cordia boissieri, Helietta parvifolia (A.DC.), Condalia hookeri (M.C. Johnst.), Diospyros texana (Sheele), Diospyros palmeri (Eastw.), Zanthoxylum fagara (L. Sarg.), Sideroxylon celastrinum (Kunth T.D. Penn), Karwinskia humboldtiana (Schult. Zucc.), Celtis pallid (Torr.) and Celtis laevigata (Willd). Leaf morphological characteristics were leaf fresh weight (g), leaf area $\left(\mathrm{cm}^{2}\right)$, leaf length $(\mathrm{cm})$, leaf width $(\mathrm{cm})$, petiole length $(\mathrm{cm})$, total leaf length $(\mathrm{cm})$, leaf dry weight $(\mathrm{g})$, leaf water content $(\mathrm{g})$ and specific leaf area $\left(\mathrm{cm}^{2} \mathrm{~g}^{-1}\right)$. The results showed that the species Cordia boissieri got the highest value in all studied variables which ranged from $0.4167 \mathrm{~g}$ (leaf water content) to $101.4605 \mathrm{~cm}^{2} \mathrm{~g}^{-1}$ (specific leaf area). In contrast, the species Diospyros texana registered the lowest value in seven variables which ranged from 0.0217 (leaf water content) to $3.186 \mathrm{~cm}$ (Leaf total length. Correlation analysis showed highly significant relationships, both positive and negative, among studied leaf traits.
\end{abstract}

\section{Introduction}

Large variatioan exists in leaf morphology within the population of the species. Various studies have demonstrated significant associations between the variation in leaf morphology and specific environmental condition of the plant species (Abrefa et al., 2011). Under abiotic stress conditions the plants alter their physiology, morphology and development in response to environmental changes. The leaves are important organs for photosynthesis and playa $\mathrm{n}$ important role for the survival and growth of the plants. The leaf form and its structure may differ within a brief period mainly during the morphogenesis of the basal primordium, thereby playing its posible role in the difusion reaction and this may be changed by allometric expansion (Xu et al., 2009). The leaves stand as an interphase between the atmosphere and the rest of the plant, thereby being responsable to mantain the carbon and water balance. At the global level, the chemical, physiological and structural variations explain parallely the distribution of the species, thereby, the species variatin is one of the te consequences of the adaptation of the plants in macro-environment.

For an example, in a high humid environment the leaves may be finer with higher leaf area compared those in dry and high temperature environment. However, it is also confirmed that there exists a spectrum of fliar variation within a determined community which may partially explain the coexistence of the species in the eco-system (Diaz et al., 1998).

The foliar morphology is basically determined on genetic basis but the leaves exposed to intense selection pressure in the environments, lead to phenotypic differences in the leaves depending on the environment where they grow and develop, thereby leading to a wide range of leaf forms and sizes (Aguiar et al., 2000). On the otherhand, the foliar traits determine the loss of water and thereby is largely related to water. A high specific leaf area indicate a greater relation between leaf surface area and volumen but greater loss of water (Lopez et al., 2013). It is documented that the decrease in leaf area reduce the transpiration in the leaves exposed to the solar radiation, thereby improve water use efficiency. Therefore, the leaves with greater biomass unit ${ }^{-1}$ area is considered more efficient both in water and nutrient use in arid environment. However these leaf characteristics might be affected by variations in nutrients, and or moisture, light intensity, temperature, altitude, concentration of $\mathrm{CO}_{2}$, in the atmosphere, seasonal variation and leaf (Navarro, 2004). 
The decrease in leaf area is attributed to change in leaf structure or owing to an increase concentrations of nutrients or noncarbohydrates in the same, therefore this decrease in leaf area is the result of the incapacity of the plant for assigning these compounds in its structural growth There after the study on leaf area is important (Perez et al., 2004).

In this respect very limited studies have been undertaken in Tamaulian Thorn Scrub on leaf traits. The present study was undertaken to dtermine the morphological variatios of ten species of Tamaulipan Thorn Scrub.

\section{Materials and Methods}

The study was undertaken in January and June 2015, in the municipality of Linares, Nuevo Leon in Forest Faculty of

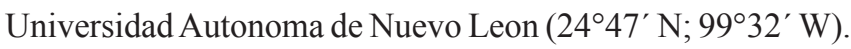
The type of climate according to Koppen (1938), modified by Arcia (1981), (Gonzalez et al., 2000) present subtropical and semiarid condition with hot summer. The average monthly air temperatures oscillate between $14.7^{\circ} \mathrm{C}$ in January to $3{ }^{\circ} \mathrm{C}$ in August, although the common temperature in summer is 45 ${ }^{\circ} \mathrm{C}$. The average annual precipitation is approximately 805 $\mathrm{mm}$ with a bimodal distribution. Thesoils are deep vertisol with brown-dark. The predominant vegetation is Tamaulipan Thorn Scrub or subtropical thorn scrub. Soil is vertisol. The predominant vegetation is Tamaulipan Thorn Scrub.

\subsection{Selection of species}

According to the values of importance (economic, ecological, ltural, etc.) 10 speciesn of shrubs, 5 individuals species ${ }^{-1}$ and 10 leaves from each individual from each species thereby giving total of total of 500 , Table 1 .

\subsection{Determination of morphological characteristics}

For determination of morphological characteristics, the leaves were collected from 10 species, 5 individuals from each species and 10 leaves from each individual species, tereby collecting in total 500 leaves. Meeasurement taken were, length $(\mathrm{cm})$, breadth $(\mathrm{cm})$, petiole length $(\mathrm{cm})$ manually. The leaf area $\left(\mathrm{cm}^{2}\right)$ was taken with leaf area meter LI-3000, localized in chemistry Laboratory of Forest Science Faculty.

\subsection{Statistical analysis}

Owing to the fact that the data did not show normal distribution nor homogeneity of variance, non-parametric analysis of Kruskal-Wallis was utilized to detect significant differences among shrub species for each of morphological characters studied.

In order to detect the relation among leaf characteristics, the correlation of Spearman (Ott, 1995) was utilized. The analysis has been carried out using by statistical package SPSS, version version 13 released by Windows (SPSS, 2000).

\section{Results and Discussion}

The results showed significant differences $(p<0.001)$ among the shrub species for each leaf morphological variable evaluated (Figure 1a to $1 \mathrm{i}$ and Table 2). The present reveales a wide range of inter specific diversity among distinct leaf characteristics which coincides the observation of (Quero et al., 2009) that there exist distinct functional characteristics among the plant community.

\subsection{Morphological variables}

\subsubsection{Leaf length}

With respect to leaf length, the Celtis pallida showed very low value while the species Cordia boissieri presented very high

Table 1: Shrub species selected for determination of morphological characteristics

\begin{tabular}{llll}
\hline $\begin{array}{l}\text { Sl. } \\
\text { no }\end{array}$ & Scientific name & Common name & Family \\
\hline 1. & Cordia boissieri & Anacahuita & Boraginaceae \\
2. & Helietta parvifolia & Barreta & Rutaceae \\
3. & Condalia hookeri & Brasil & Rhamnaceae \\
4. & Diospyros texana & Chapote prieto & Ebenaceae \\
5. & Diospyros palmeri & Chapote manzano & Ebenaceae \\
6. & Zanthoxylum & Colima & Rutaceae \\
& fagara & & \\
7. & Sideroxylon & Coma & Sapotaceae \\
& celastrinum & & \\
8. & Karwinskia & Coyotillo & Rhamnaceae \\
& humboldtiana & & Ulmaceae \\
9. & Celtis pallida & Granjeno & Euphorbia- \\
10. & Celtis laevigata & Palo blanco & ceae \\
\hline
\end{tabular}

Table 2: Summary of analysis of Kruskal-Wallis for detecting significant differences among shrub species for studied leaf traits

\begin{tabular}{lcc}
\hline & \multicolumn{2}{c}{ Statistical } \\
\hline Leaf characteristics & $\chi^{2}$ & Value $p$ \\
Leaf fresh weight & 426.43 & $<0.001$ \\
Leaf area & 432.93 & $<0.001$ \\
Leaf length & 415.65 & $<0.001$ \\
Leaf breadth & 431.80 & $<0.001$ \\
Petiole length & 462.10 & $<0.001$ \\
Total leaf length & 437.78 & $<0.001$ \\
Leaf dry weight & 428.71 & $<0.001$ \\
Leaf water content & 406.34 & $<0.001$ \\
Specific leaf area & 234.12 & $<0.001$ \\
\hline
\end{tabular}



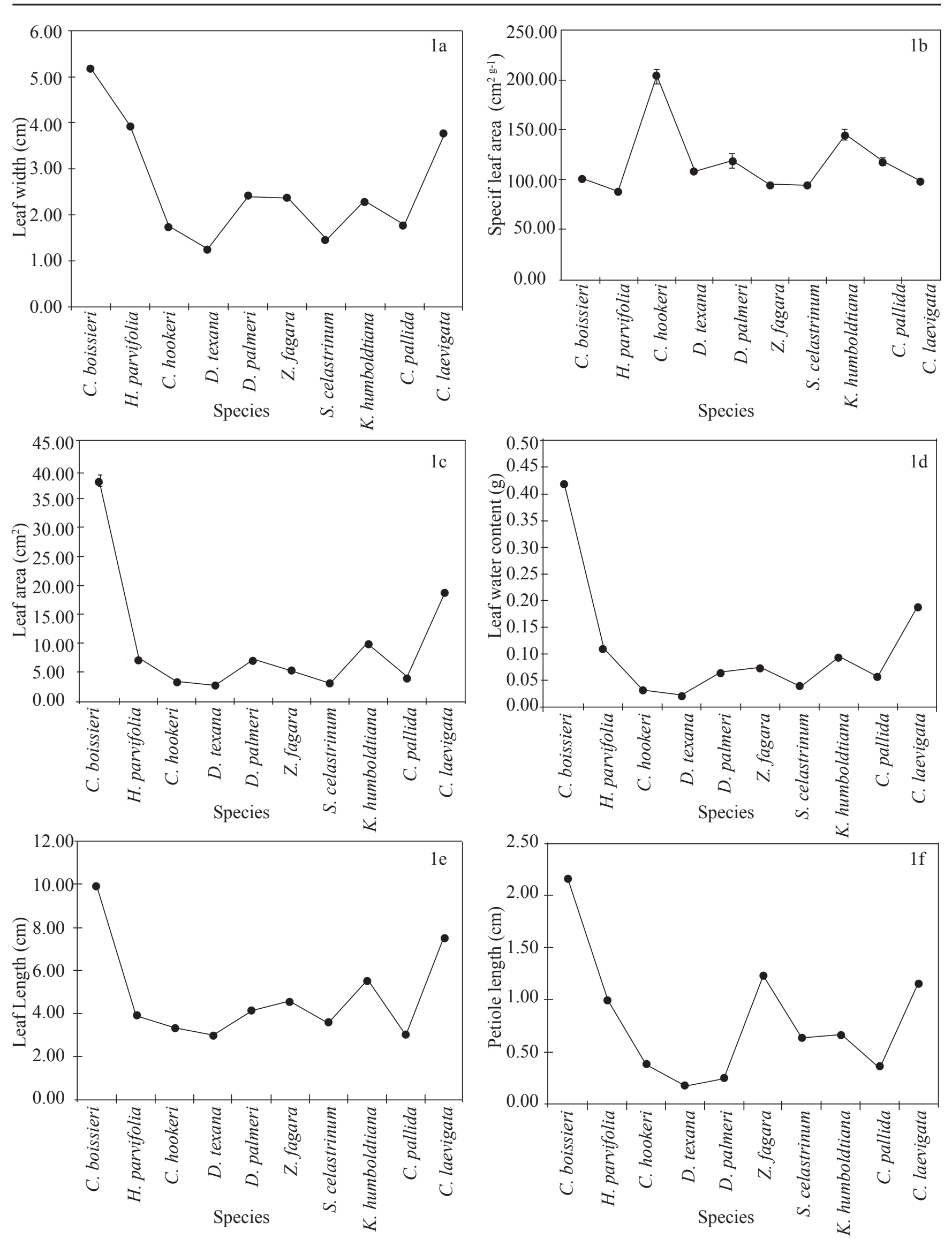

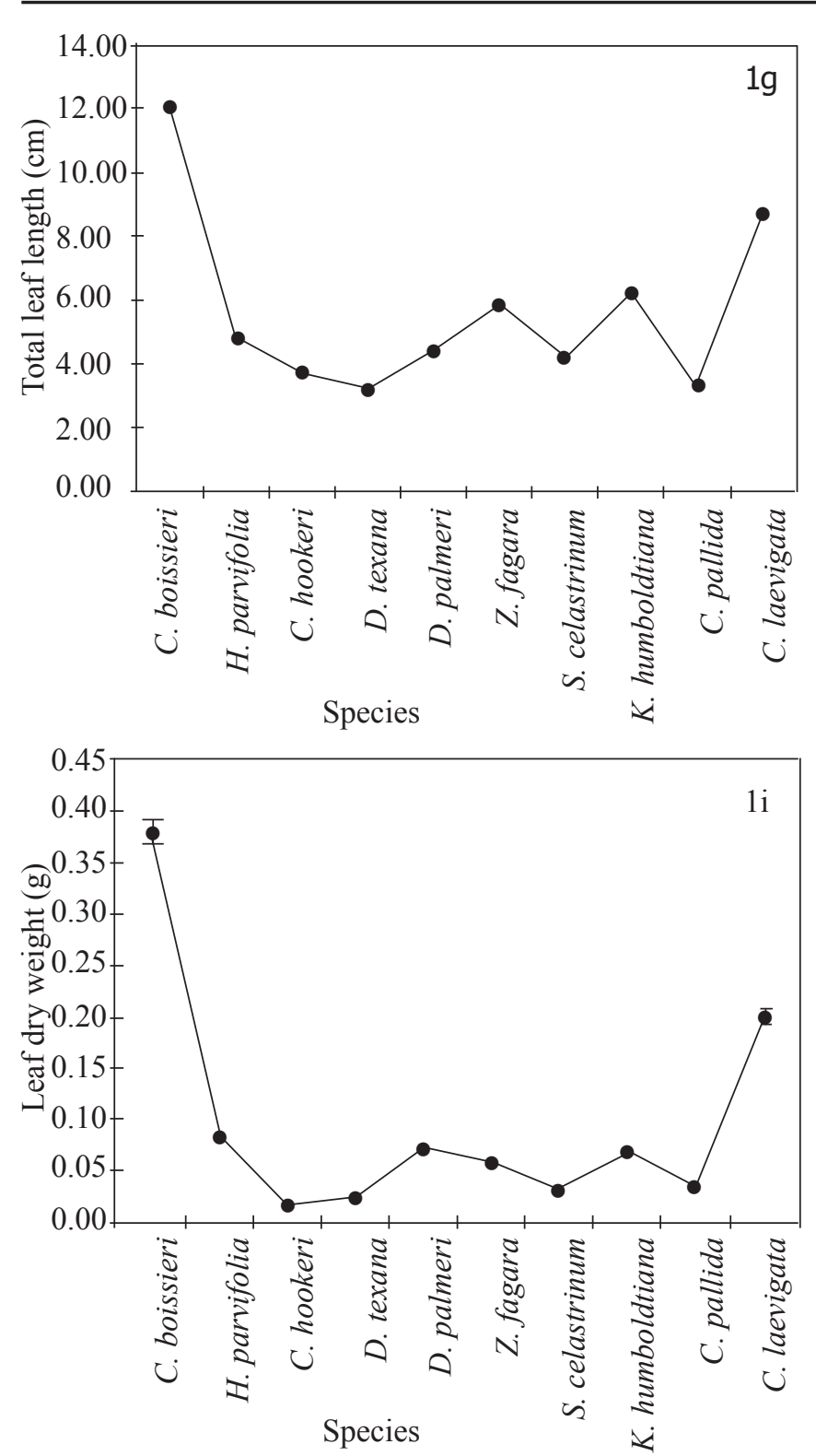

Figure 1a to 1i: Morphological leaf characteristics of 10 species of Tamaulipan Thorn Scrub, represented graphically, average $(\mathrm{n}=50)$, standard error \pm

value, the values were 2.9 and $9.8 \mathrm{~cm}$, respectively amante. It may be inferred that a higher value of leaf area represents higher transpiration.

\subsubsection{Leaf breadth}

With respect to leaf breadth with greater value was obtained in Cordia boissieri with $5.1 \mathrm{~cm}$ and the species with very low value was found in Diospyros texanawith $1.2 \mathrm{~cm}$. The results demonstrate that very high value of leaf breadth indicate that the very high value of was found in oval leaf and high transpirable leaf area.

\subsubsection{Specific leaf area $\left(\mathrm{cm}^{2} \mathrm{~g}^{-1}\right)$}

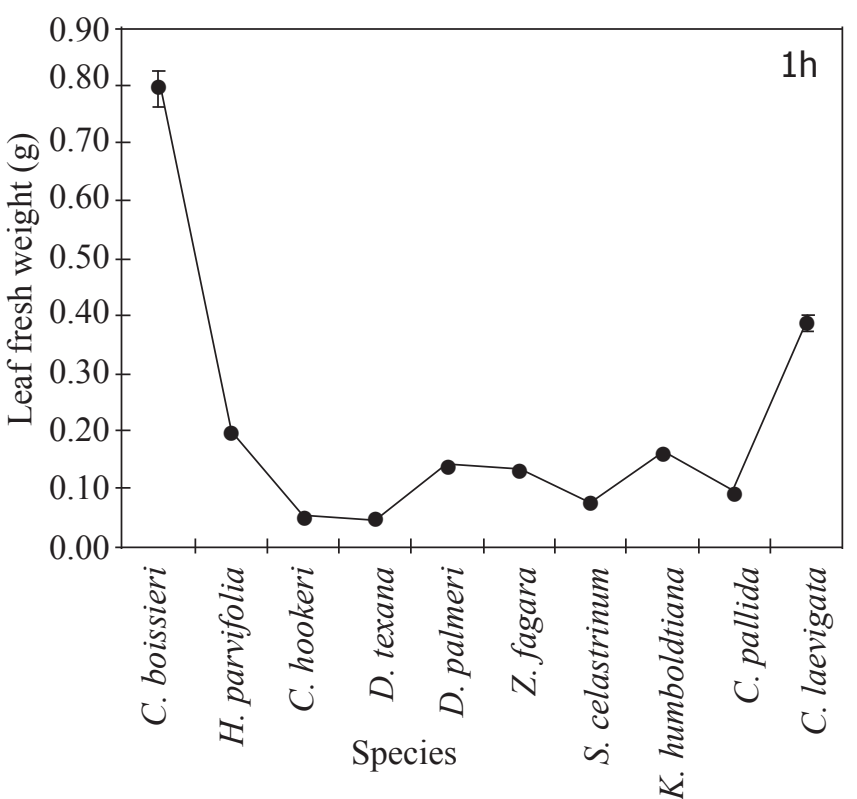

With respect specific leaf area, the very high value was observed in Condalia hookeri $\left(204.1 \mathrm{~cm}^{2} \mathrm{~g}^{-1}\right)$ while the species with low value was obtained in Helietta parvifolia $\mathrm{p}\left(88.5 \mathrm{~cm}^{2}\right.$ $\left.\mathrm{g}^{-1}\right)$. The specific leaf area expressses the relative thickness of the leaves and is a morphological characteristic, sensitive to environments (Santos and Segura, 2005). The specific leaf area explain the greater part of variation of growth among the species. The especies with rapid growth under optimum conditions are those with greater specific leaf area (Poorter and Garnier, 1996). The specific leaf leaf area is leaf area its dry ${ }^{-1}$ weight. An increase in specific leaf area that the leaf use low biomass unit ${ }^{-1}$ leaf area.

\subsubsection{Leaf area $\left(\mathrm{cm}^{2}\right)$}

Th especies Cordia boissieri had greater leaf area and the species with very low value was found in Diospyros texana, with the values of $7.9 \mathrm{~cm}^{2}$ and $2.6 \mathrm{~cm}^{2}$, respectively. The lower leaf area indicate that it reduces incidence of light in te plant crown, depending on the orientation, distribution and leaf sizes. In decidous shrubs have rought escape capacity and are considered highly adapted to the conditions of prolonged water, the common strategy adapted is the reduction of leaf area mainly. by seasonal loss of leaves (Pereira and Chavez, 1993).

\subsubsection{Leaf water content}

Diospyros texana showed minimu, moisture content while the species Cordia boissieri had greater value; these values were 0.02 and $0.41 \mathrm{~g}$, respectively. It may be inferred from the results that this species of Tamaulipan Thrn Scrub to more tolerant to descication which may be due to to smaler microphyls of the leaves. which allow to reduce the high rate of 
transpiration flowlo y por consequently contain higher greater moisture content in the leaf tissue which has been documented (Gonzalez et al., 2000). Salisbury and Ross (1994) inferr that the reduction of water content is accompamied by the loss of turgour and withering, ceasescell expansion, closes stomatas, reduces photosynthesis and the interference of many other metabolic processes. It is documented thdecrease in leaf area reduce transpiration in the leaves exposed to radiatins, this in turn improve water use efficiency (Salisbury and Ross, 1994).

\subsubsection{Petiole length}

Th especies Cordia boissieri had greater petiole length with 2.1 and very low value was observed in Diospyros texana with 0.2 $\mathrm{cm}$. The greaer value of petiole length favor greater capture of solar radiation, on the contrary in the species with short petiole, the leaves receive low quantity of light for photosynthesis.

Total leaf length fluctuated $12.0 \mathrm{y}$ and $3.1 \mathrm{~cm}$, in the species Cordia boissieri and Diospyros texana, respectively. The higher value of total length indicate tat that thetranspirable is greater, the water content is greater and the capture of solar radiation is greater.

\subsubsection{Leaf fresh weight}

The species with greater fresh weight was observed in the species Cordia boissieri with 0.79 and the species with very low value was obtained in Diospyros texana with $0.04 \mathrm{~g}$, respectively. The difference of fresh weight between species indicate the diferencia water use water, the higher value in the species present higher water content ori s related to the depth of root system for having higher Access or the availability of moisture in the soil profile.

\subsubsection{Leaf dry weight}

Th species Condalia hookeri had lower leaf dry weight with 0.01 and the species Cordia boissieri presented greater value with $0.38 \mathrm{~g}$. The leaves with greater quantity of biomass unit $^{-1}$ area is considered more efficient in water use and also in nutrieny use. However this may be affected by variations in nutrients and or moisture, light intensity. Altitud, atmospheric concentrations of $\mathrm{CO}_{2}$, seasonal variations and leaf age (Navarro, 2004).

\subsection{Relationships among leaf traits}

Correlation: In the Table 3 is shown the correlation coefficients (Spearman) and significance value $(p<0.001)$ demonstrating that each morphological characteristic is associated with others in 10 species studied. The values of correlation showed satistically significant positive and significant correlation for variables, fresh weight, leaf area, leaf length and total leaf length, dry weight, moistue content in the leaf. The values fluctuated from 0.672 to 0.984 . On the contrary, a statistically significant negative correlation was found between specific leaf area with the rest of the variables, the vaies fluctuated from -0.125 to -0.448 . The associations among distinct foliar traits were observed, although these associations may vary in some cases bserved by some authors (Quero et al., 2009; Gotsch et al., 2010).

\begin{tabular}{lccccccccc}
\hline \multicolumn{1}{l}{ Table 3: Spearman correlation coefficients $(\mathrm{n}=500)$} & \multicolumn{10}{l}{} \\
\hline Variable & $\mathrm{V}_{1}$ & $\mathrm{~V}_{2}$ & $\mathrm{~V}_{3}$ & $\mathrm{~V}_{4}$ & $\mathrm{~V}_{5}$ & $\mathrm{~V}_{6}$ & $\mathrm{~V}_{7}$ & $\mathrm{~V}_{8}$ & $\mathrm{~V}_{9}$ \\
\hline $\mathrm{V}_{1}$. Leaf fresh weight & & 0.948 & 0.870 & 0.904 & 0.751 & 0.887 & 0.984 & 0.981 & -0.373 \\
$\mathrm{~V}_{2}$. Leaf area & $<0.001$ & & 0.901 & 0.919 & 0.672 & 0.890 & 0.928 & 0.934 & -0.125 \\
$\mathrm{~V}_{3}$. Leaf length & $<0.001$ & $<0.001$ & & 0.774 & 0.731 & 0.980 & 0.861 & 0.852 & -0.160 \\
$\mathrm{~V}_{4}$. Leaf breadth & $<0.001$ & $<0.001$ & $<0.001$ & & 0.736 & 0.809 & 0.881 & 0.892 & -0.225 \\
$\mathrm{~V}_{5}$. Petiole length & $<0.001$ & $<0.001$ & $<0.001$ & $<0.001$ & & 0.842 & 0.727 & 0.750 & -0.335 \\
$\mathrm{~V}_{6}$. Total leaf length & $<0.001$ & $<0.001$ & $<0.001$ & $<0.001$ & $<0.001$ & & 0.876 & 0.872 & -0.220 \\
$\mathrm{~V}_{7}$. Leaf dry weight & $<0.001$ & $<0.001$ & $<0.001$ & $<0.001$ & $<0.001$ & $<0.001$ & & 0.941 & -0.448 \\
$\mathrm{~V}_{8}$. Water content & $<0.001$ & $<0.001$ & $<0.001$ & $<0.001$ & $<0.001$ & $<0.001$ & $<0.001$ & & -0.302 \\
$\mathrm{~V}_{9}$. Specific leaf area & $<0.001$ & 0.005 & $<0.001$ & $<0.001$ & $<0.001$ & $<0.001$ & $<0.001$ & $<0.001$ & \\
\hline
\end{tabular}

\section{Conclusion}

The morphological characteristics of the shrub species of Tamaulipan Thorn Scrub studied showed significant difference among the speciess $(p<0.001)$, which favor the the estabishment of the species in the climatic conditions prevalent in the regionIt is observed that there exist positive and significant correlations among the variables, fresh weight, leaf area, leaf length, leaf breadth, petiolelength, total leaf length, dry weight and moisture conent of the leaves on the contrary, specific leaf area showed negative correlation with all the variables studied.

\section{Acknowledgement}

Thanks are due to to Consejo Nacional de Ciencia y Tecnologia (CONACYT) for financing Master program to the first auto Elsa Gonzalez, Don Manuel Hernandez an Jonathan. 


\section{References}

Abrefa-Danquah, J., Appiah, M., Ari, P., 2011. Leaf morph metric variation in two species of African Mahoganies: Khaya ivorensis and Khaya anthotheca (Meliaceae). European Journal of Scientific Research 54, 325-338.

Aguiar, M.O., De Morais, R.R., Araujo, R.C., Skatulla, M., Preisinger, H., 2000. Morphological traits and ecological behavior of selected secondary forest tree. GermanBrazilian Workshop on Neotropical Ecosystems 3, 965-968.

Diaz, S., Marcelo, C., Fernando, C., 1998. Plant functional traits and environmental filters at a regional scale. Journal of Vegetation Science 9, 113-122.

Gonzalez, R.H., Cantu, S.I., Gomez Meza, M.V., Jordan, W.R., 2000. Seasonal plant water relationships in Acacia berlandieri. Arid Soil Research and Rehabilitation 14, 343-357.

Gotsch, S.G., Powers, J.S., Lerdau, M.T., 2010. Leaf traits and water relations of 12 evergreen species in Costa Rican wet and dry forests: patterns of intra-specific variation across forests and seasons. Plant Ecology 211, 133-146.

Lopez-Iglesias, B., Villar, R., Poorter, L., 2013. Rasgos funcionales como indicadores de la respuesta a la sequia en plantulas de 10 especies lenosas mediterraneas. Sociedad Espanola de Ciencias Forestales, 10.

Navarro-Ruiz, P., 2004. Variacion en la morfologia foliar de especies mediterraneas procedentes de sitios con diferente disponibilidad de suelo y agua. Naturzale 18, 169-193.

Ott, L., 1993. An introduction to statistical methods and data analysis $2^{\text {nd }}$ Edn. Duxbury Press. Boston, Massachusetts,
United State American 775.

Pereira, J.S., Chavez, M.M., 1993. Plant water deficits in Mediterranean ecosystems. In: Smith, J.A.C., Griffiths, H., (Eds.), Water deficits plant responses from cell to community: 221-236. BIOS Scientific Publishers Limited, Oxford.

Perez-Amaro, J.A., Garcia-Moya, E., Enriquez-Quiroz, J.F., Quero-Carrillo, A.R., Perez-Perez, J., Hernandez-Garay, A., 2004. Analisis de crecimiento, area foliar especifica y concentracion de nitrogeno en hojas de pasto "mulato" (Brachiaria hibrido, cv.). Revista Mexicana de Ciencias Pecuarias. Tecnologico Per. Mexico 42, 447-458.

Poorter, H., Garnier, E., 1996. Plant growth analysis: an evaluation of experimental design and computational methods. Journal Experimental Botany 47, 1343-1351.

Quero, J.L., Villar, R., Poorter, L., Maranon, T., Matias, L., Aponte, C., Garcia, L.V., Casado, R., Herrero, A., Suarez, E., Navarro, C.R.M., Zamora, R., 2009. Espectro de variacion foliar en bosques mediterraneos del sur de la Peninsula Iberica. Sociedad Espanola de Ciencias Forestales. Actas $5^{\circ}$ Congreso Forestal Espanol 2-11.

Salisbury, E., Ross, C., 1994. Fisiologia vegetal. Grupo Editorial Iberoamerica, Mexico. 37-40.

SPSS, 2000. Statistical Package for the Social Sciences. Standard released version 13 for Windows, SPSS Inc., Chicago, IL. USA.

Xu, F., Guo, W., Xu, W., Wei, Y., Wang, R., 2009. Leaf morphology correlates with water and light availability: What consequences for simple and compound leaves? Progress in Natural Science 19, 1789-1798. 